\title{
First Local Transmission Cluster of COVID-19 in Malaysia: Public Health Response
}

\author{
Noor Ani Ahmad ${ }^{*}$, Chong Zhuo Lin', Sunita Abd Rahman², Muhammad Haikal bin Ghazali ${ }^{3}$, Ezy Eriyani \\ Nadzari ${ }^{4}$, Zazarida Zakiman ${ }^{5}$, Suziana Redzuan ${ }^{4}$, Salina Md Taib ${ }^{5}$, Mohd Shaiful Azlan Kassim ${ }^{1}$, Wan Noraini \\ Wan Mohamed Noor
}

${ }^{1}$ Institute for Public Health, Ministry of Health Malaysia, 40170 Shah Alam, Selangor, Malaysia

${ }^{2}$ Crisis Preparedness and Response Centre (CPRC), Kedah State Health Department, Ministry of Health Malaysia, 05400

Alor Setar, Kedah, Malaysia

${ }^{3}$ Crisis Preparedness and Response Centre (CPRC), Selangor State Health Department, 40100 Shah Alam, Selangor, Malaysia

${ }^{4}$ Kuala Muda District Health Office, Ministry of Health Malaysia, 08000 Sg Petani, Kedah, Malaysia

${ }^{5}$ Petaling District Health Office, Petaling Jaya, Selangor, Malaysia

${ }^{6}$ National Crisis Preparedness and Response Centre (CPRC), Disease Control Division, Minsitry of Health Malaysia, 62590

WP Putrajaya, Malaysia

Corresponding Author: Noor Ani Ahmad, MD, Institute for Public Health, Ministry of Health Malaysia, Block B5, NIH Complex, No.1, Jalan Setia Murni U13/52, Seksyen U13, Setia Alam, 40170 Shah Alam, Selangor, Malaysia. Tel: +60333628700, Email: drnoorani@moh.gov.my,dr.ani1006@gmail.com

Received June 28, 2020; Accepted July 23, 2020; Online Published July 30, 2020

\begin{abstract}
Introduction: Rapid public health response is important in controlling the transmission of coronavirus disease 2019 (COVID-19). In this study, we described the public health response taken by the Ministry of Health of Malaysia in managing the first local transmission cluster of COVID-19 related to mass-gathering and inter-state traveling to celebrate a festival.

Methods: We summarized strategies implemented by the Malaysia Crisis Preparedness and Response Centre (CPRC) in managing the first local transmission of COVID-19. We collected information related to the epidemiological investigation of this cluster and described the inter-state network in managing the outbreak.

Results: This first local transmission of COVID-19 in Malaysia had a history of contact with her older brother, the index case, who was the first Malaysian imported case. Only two positive cases were detected out of 59 contacts traced from the index case. Close contacts with infected person/s, inter-state movement, and public/family gatherings were identified as the sources of transmission. A large number of contacts were traced from inter-state traveling, and family gatherings during the festive season, and health consultations and treatment. Conclusion: Close contacts from inter-state movement and public/family gatherings were identified as the source of transmission. Family or public gatherings during festivals or religious events should be prohibited or controlled in COVID-19 prevalent areas. A structured surveillance system with rapid contact tracing is significant in controlling the transmission of COVID-19 in the community.

Keywords: COVID-19, Travelling, Festival, Malaysia
\end{abstract}

Citation: Ahmad NA, Lin CZ, Abd Rahman S, et al. First local transmission cluster of COVID-19 in Malaysia: public health response. Int J Travel Med Glob Health. 2020;8(3):124-130. doi:10.34172/ijtmgh.2020.21.

\section{Introduction}

China reported a cluster of pneumonia of unknown origin in Wuhan city late December 2019. ${ }^{1}$ The causative pathogen was a novel coronavirus ( $\mathrm{nCoV}$ ), later known as Severe acute respiratory syndrome coronavirus 2 (SARS-CoV-2). The disease was officially named coronavirus disease 2019 (COVID-19). ${ }^{2}$ Since then, the disease has spread rapidly through China and to other parts of the world. As of 27 June 2020, the World Health Organization (WHO) reported roughly ten million confirmed cases, with almost 500000 deaths worldwide. ${ }^{3}$ In Malaysia, a total of 8634 cases were reported up to June 28,2020 , with 121 deaths, and two cases under treatment in intensive care unit with 18 new reported cases, of which three were Malaysian. ${ }^{4}$ Malaysia is one of the countries which is showing a reduction in COVID-19 infection rate following various strategies to control this unprecedented outbreak. 
The first case of COVID-19 was reported in Malaysia on 25 January 2020. ${ }^{5}$ This first case and all seven cases that followed were all imported cases of Chinese nationals, five of whom originated from Wuhan itself. ${ }^{5,6}$ Subsequent cases were all imported until 5 February 2020, when Malaysia reported its first-ever local transmission cluster. ${ }^{7}$

After the WHO confirmed the cluster of pneumonia of unknown origin in China on 5 January 2020, the Ministry of Health of Malaysia ( $\mathrm{MOH})$ immediately activated various preparedness and response activities through its Crisis Preparedness and Response Centre (CPRC) ${ }^{8,9}$ CPRC was first established in 2007 under the supervision of the Ministry of Health of Malaysia to be the focal point for the management of health-related crises and disasters. It coordinates all activities related to crisis preparedness, response, and recovery, including coordination with international organizations, non-governmental organizations, and private sectors. ${ }^{10}$

Since its establishment, the CPRC has been playing its role to manage all major outbreaks in Malaysia, including the endemic infectious diseases such as dengue, with its weekly reports to top management; and sporadic cases such as rabies and vaccine-preventable diseases, while preparing and responding to newly-emerging infectious diseases such as Middle East respiratory syndrome coronavirus (MERS$\mathrm{CoV}$ ) and avian influenza A (H7N9). ${ }^{11}$ This study reported the preparedness and public health response received by CPRC surrounding the detection and control of the first local transmission cluster of COVID-19 in Malaysia.

\section{Patients and Methods}

\section{Case Definition}

The "Interim Guidelines for Management of Novel Coronavirus (nCov) in Malaysia"12 released in January 2020 defined:

"Person under investigation (PUI) of Novel Coronavirus (nCoV): a person with fever; AND clinical sign/symptoms suggestive of pneumonia OR severe respiratory infection with breathlessness; AND had a history of travel to (excluding transit) or reside in Wuhan City, China within the last 14 days, OR close contact with a confirmed case of novel coronavirus $(\mathrm{nCoV})$.

Confirmed case of $\mathrm{nCoV}$ : a person with laboratory confirmation of infection with the Novel Coronavirus (nCoV).”

\section{Surveillance}

All travellers from Wuhan, China were required to undergo temperature screening by public health teams. Travellers with a temperature of $\geq 38^{\circ} \mathrm{C}$ would be investigated further. Travellers and crew allowed to disembark would be given a Health Alert Card. In addition, dissemination of information regarding the disease to the public, travellers, and the crew was also made available. To ensure all the steps above were executed, the $\mathrm{MOH}$ collaborated with the Immigration Department of Malaysia, airport/seaport/ground border crossing authorities and agencies, commercial airlines, freight companies, ground handlers, and other relevant agencies. ${ }^{8,12}$ All public and private outpatient clinics and emergency departments were required to screen and triage their patients for PUI. Upon detection, the nearest District Health Office (DHO) should be immediately notified and the PUI referred to one of the 26 public hospitals which are designated for the admission and treatment. Based on the Prevention and Control of Infectious Disease Act 1988 (Act 342), the hospital was made mandatory to notify DHO upon admission and diagnosis of any person fulfilling the case definition. . $^{8,912,13}$

Upon admission of PUIs to the abovementioned COVID-19 designated hospital, upper or lower respiratory tract specimens would be sampled from them and sent to designated research, public health, and hospital laboratories nationwide equipped to perform reverse transcriptase polymerase chain reaction (RT-PCR) for the diagnosis or exclusion of COVID-19.9,12

A separate surveillance system was established on top of the existing Malaysia Influenza Surveillance i.e. COVID-19 Surveillance System; whereby different sentinel sites were identified nationwide. ${ }^{14}$ The samples, amounting to five to ten samples are daily sent to the designated laboratories at the Institute for Medical Research, Public Health Laboratories and designated hospitals. ${ }^{9}$

\section{Epidemiological Investigation and Management}

Upon diagnosis of a COVID-19 case, the DHO would receive a notification. Once it was verified and validated, the DHO would deploy Rapid Assessment Team (RAT) and the Rapid Response Team (RRT). The RAT would proceed with case investigation that includes collecting patient's sociodemographic information, clinical symptoms and the date of onset, and more importantly, patient's travel and movement history over the past 14 days to determine the date of exposure and to establish a close contact line listing for contact tracing. ${ }^{12-14}$

In the first guideline released by CPRC, close contact was defined as (a) anyone who provided care for the patient, including a healthcare worker or family member; OR $(b)$ anyone who had other similar close physical contacts; OR (c) anyone who stayed (e.g. lived with, visited) at the same place as a case. The RAT would perform the contact tracing and investigate each of them and arranging for collection of upper respiratory specimens, regardless of whether they reported symptoms or not. ${ }^{9-11}$

All PUIs detected initially were required to be admitted for isolation in COVID-19 designated hospitals, while waiting for test results. ${ }^{12,15}$ The transfer of a PUI from their home, would be handled by RRT of respective DHO that received the notification, using a designated ambulance. The same also is applied to confirmed cases. ${ }^{12}$

Epidemiological investigation and identification of all close contacts were done by districts where the contacts stay. After samples were taken, the contacts of confirmed COVID-19 cases would be quarantined at designated places or home for 14 days under the Act, with their conditions being monitored daily by the relevant DHO, and only admitted when their results returned positive. ${ }^{12}$

Health facilities were advised on standard precautions such as hand hygiene practice, use of personal protective equipment (PPE), and environmental control procedures such 
as ventilation, cleaning, disinfection, and waste management. Other measures included clinical triage for early and rapid identification of cases mentioned above, dedicated waiting areas with physical distancing, isolation room with negative pressure if possible, packing and transport of items in contact with a patient, etc. When handling a case, standard and airborne precautions were recommended when performing aerosol-generating procedures. ${ }^{8,9,12}$

The CPRC also monitored closely the spread of COVID-19 in China and elsewhere, especially in neighbouring countries such as Thailand and Singapore. Information on laboratoryconfirmed cases among travellers is communicated through respective International Health Regulations (IHR) Focal Points. ${ }^{9}$

\section{Results}

The detection and control of the first local transmission cluster of COVID-19 in Malaysia was a collaborative effort of National and State CPRC, as well as the relevant DHO, in which all cases involved in this cluster lived. This cluster is presented in a chronological order below for a better understanding.

\section{Index Case of First Local Transmission Cluster}

The first local transmission cluster began from the first Malaysian imported case, called Mr. A. Mr. A is a Malaysian man aged 41-year-old without co-morbidity. He lives in Selangor state and is a professional working from home for a foreign company. On January 16, 2020, he travelled alone to Singapore and checked in at a hotel, which was also the venue of a business conference he was going to attend. The conference lasted from 20 to 22 January 2020 and was also attended by delegates from other countries, including from China. While in Singapore, Mr. A also visited some places around the hotel but did not go to the zoo or market. Neither did he eat any raw food, nor had any contact with animals or sick people.

On January 23, 2020, Mr. A developed fever, cough, and runny nose, before he boarded the return flight to Malaysia. Upon touching down at Kuala Lumpur International Airport (KLIA), he met his wife and boarded another domestic flight together to a northern state in Malaysia. He was picked up by his younger sister and brought to a private clinic for consultation before sent to their mother's home to celebrate Chinese New Year. He stayed there most of the time during the festival, except for another visit to a private hospital on 24 January. After he flew back to Selangor, within 26 to 28 January, he had a communal meal each day with the relatives of his wife including his mother-in-law to celebrate the festival. On 28 January, he went to another private clinic for treatment. He was admitted to a private hospital for inpatient treatment the next day. On 2 February, he was referred as a PUI, based on the Guideline, and sent by RRT to a COVID-19 designated public hospital for sampling and isolation, where he was tested positive the next day. There, he remained stable throughout and was discharged on 17 February and was then home quarantined for 14 days.
Petaling DHO in Selangor state was notified about Mr. A's admission on 2 February, and the positive result on the next day. Contact tracing was started on 3 February within 24 hours of notification. Other districts in Selangor were notified immediately by Petaling DHO, while Selangor CPRC notified its counterparts at Kedah state. Contact tracing revealed 59 close contacts, mostly from the private hospital at Petaling district (40 contacts), private clinic and hospital at Kuala Muda district (eight contacts), and immediate family members (seven contacts), some of whom live in other districts and states. On 4 February, other relevant DHOs began to trace down and manage all other contacts. Out of these close contacts, two were tested positive.

First Local Transmission and First Generation of the Index Case

The first local transmission in Malaysia that was also the first case of the first generation of the index case was Mr. A's younger sister, Mdm B. Mdm B is a 40-year-old lady without co-morbidity. She lives in Kedah. She is a supervisor in the local industry. She did not have foreign travel history. As mentioned above, Mdm B first came into contact with Mr. A while fetching him from Penang airport on 23 January. On 24 January, Mdm B went to a local market to shop for supplies in preparation for the festival. She then spent most of her following days until 3 February at her mother's house, where she came into contact with Mr. A repeatedly. In between, she and her immediate family visited other relatives at Penang on 25 January, sent Mr. A and wife to Penang airport on 26 January, watched movies in the cinema on 26 and 27 January, sent her children to school and back from 28 to 30 January, and fetched her sister from Penang to her mother's house on 31 January.

On 1 February, Mdm B began to have a fever and sore throat, for which she went to buy medication at a private clinic. On 3 February, she went to work at her workplace in another district in Kedah (Baling district) for a while early in the morning and met five co-workers. On 4 February, after she sent her children to school, she was traced by Kuala Muda DHO where she lives to her mother's house and was quarantined at home. The samples were taken from Mdm B and her family members in the evening, in which Mdm B was tested positive on 5 February. She was admitted by RRT and isolated on the same day. She was asymptomatic throughout her stay and was discharged on 22 February, after which she was quarantined at home for another 14 days. Contact tracing was initiated by Kuala Muda DHO on 5 February and Baling $\mathrm{DHO}$ was also notified. Twelve close contacts of her, namely seven immediate family members, and five co-workers were all tested negative and were quarantined for 14 days.

The second case was Mr. A's mother-in-law, Mdm C. She is a 65-year-old lady with diabetes mellitus, hypertension, and ischaemic heart disease on a pacemaker. She suffered from a left cerebrovascular accident with right hemiparesis, which rendered her dependant on activities of daily living. Mdm C met Mr. A during a family dinner held in conjunction with the Chinese New Year festival on 26 January, when the latter flew back into Selangor state as mentioned above. Thirty-six 
people attended the dinner and were seated around three round tables. Mdm C and Mr. A sat around the same table but had no physical contact except the initial greeting holding hands. On the following two days, Mdm $\mathrm{C}$ attended lunch and dinner on each day with the same family members. On both occasions, she was also seated around the same table as Mr. A. Mdm C stayed home with her husband, son, and helper from 29 January to 4 February.

On 5 February, Mdm C was brought to a private hospital with complaints of dizziness, sweatiness, and lethargy. She did not have a fever. She was seen in the emergency department, sent for a CT-brain, and then discharged with a planned MRI brain in two days. She stayed home with the abovementioned three people in the next day. On 7 February, after going for the MRI through the emergency department of the same private hospital, she was brought to a public clinic in Petaling DHO for SARS-CoV-2 sampling as a close contact with Mr. A together with six others and was given home quarantine. Her result came back positive on 8 February and she was admitted by RRT immediately. No symptom was reported throughout her isolation in the ward until discharge on 19 February. All 36 close contacts of her, from the dinner, were tested negative and were quarantined for 14 days.

On the other hand, instructions were given by DHOs to disinfect clinics and hospitals involved with treating all COVID-19 patients in this first local transmission cluster prior to their diagnosis, as well as the residences they stayed or live in.

A detailed timeline of the first local transmission of COVID-19 in Malaysia is illustrated in Table 1.

\section{Discussion}

This article described the preparedness and strategies adopted by the Ministry of Health of Malaysia in facing an outbreak and pandemic. The establishment of CPRC in Malaysia ensured rapid communication at international and inter-state levels. In fact, it was only after the detection of Mr. A in Malaysia as Singapore and other countries were aware of this hotellinked cluster that spread to a few countries. ${ }^{16-18}$ Locally, Kuala Muda DHO, situated $400 \mathrm{~km}$ away from Petaling district, was able to trace and sample Mdm B on 4 February after Petaling DHO completed its case investigation on the index case on 3 February. A similar mechanism of rapid communication was also reported in France, where a confirmed case has to be reported immediately through around-the-clock available phone line to the Regional Health Agency, which will then inform three agencies: hospital infection control teams, the French Public Health Agency and the Ministry of Health. ${ }^{19}$ Early identification, sampling, and quarantine of contacts are important to curb the spread of COVID-19 as this is a highly contagious illness. Experience from China described that it had spread from Wuhan to the entire country within only 30 days. $^{20}$

The epidemiological investigations conducted by both Kuala Muda and Petaling DHO were also quite complete and extensive. The contacts traced for Mr. A, Mdm B, and Mdm C reached 59, 12, and 36 people, respectively. For comparison, Korea reported an average of 79 contacts per case reported in
Korea, but it was skewed by a wide range from two contacts for one case to 649 for another. ${ }^{21,22}$ Large number of contacts from Mr. A was mostly from the private hospital where he was hospitalised for four days. He was only referred to COVID-19 designated public hospital when his condition did not improve with treatment together with travel history to Singapore. Locally at the same time, there were eight imported cases from Singapore to Malaysia. ${ }^{6}$ This delay is unavoidable as at this stage the definition of PUI was based on the history of travel to Wuhan.

Kuala Muda DHO identified only 12 close contacts of Mdm B. Even though Mdm B was quite mobile before she developed symptoms, as most of her encounters were brief; less than 15 minutes, and were not considered as close contacts. Only close contacts of more than 30 minutes beginning from one day prior to symptom onset were sampled and quarantined. ${ }^{23}$ In contrast, a relatively large number of contacts traced for $\mathrm{Mdm}$ $\mathrm{C}$ from just one event, contributed by the family gathering for reunion dinner to celebrate Chinese New Year.

This cluster highlights a major challenge in managing an outbreak such as COVID-19, i.e. the interconnectedness of people from different parts of the world, which increases not only the speed of disease transmission but also the extent of it. ${ }^{17}$ Our index case only had a travel history to Singapore attending a close business conference but had a contact there with 111 participants from 19 different countries, of whom 17 were from China and at least one was from Wuhan. ${ }^{16-18}$ As such, despite the quick release of interim guidelines, our index case did not fulfil the case definition. He bypassed the temperature screening at the airport and went under the radar for 14 days after the first exposure; and was only suspected as PUI on day 8 after symptoms onset, or day 5 after admission. Another factor contributed to the late case detection was also due to the unfamiliarity towards this infection initially, especially from the private healthcare facilities.

The interconnectedness of people also facilitated interstate spread in Malaysia. Families are increasingly separated by distance and living in different places. Long-distance travelling and family gathering around seasons of the festival could result in numerous close contacts and the potential of spreading the infection..$^{20,24}$ In our case, Mr. A travelled back and forth on flights and had close contact multiple times over four days with $\mathrm{Mdm} \mathrm{B}$, and three times over communal meals with Mdm C, which substantially increased the chance of disease transmission. The epidemiological investigation in China also revealed similar important factors that contributed to the inter-state spread, i.e. return home to celebrate Chinese New Year with family. ${ }^{20,24}$ This annual cultural celebration is an important event for the Chinese community worldwide. However, the long-distance travelling and family gatherings during the celebration result in numerous close contacts and the potential of spreading the illness such as this case. Fortunately, swift subsequent prevention and control measures taken in our case managed to stop the chain of transmission quickly, both locally and internationally. ${ }^{17}$ Family gathering for an event such as the one in this study predisposed to a familial cluster, which was also reported elsewhere..$^{25,26}$

As this is the first local transmission detected in the early 
Table 1. Timeline of the Index Case and Local Transmission of COVID-19

\begin{tabular}{|c|c|c|c|}
\hline Date & Index Case (Mr. A) & First Local transmission (Mdm B) & $\begin{array}{l}\text { Second case of local transmission (Mdm } \\
\text { C) }\end{array}$ \\
\hline Jan 16 & Went to Singapore & \multirow{2}{*}{$\begin{array}{l}\text { No travel history } \\
\text { Live in Kuala Muda District, Kedah state, Malaysia }\end{array}$} & \multirow{5}{*}{$\begin{array}{l}\text { No travel history } \\
\text { Live in Petaling District, Selangor state, } \\
\text { Malaysia }\end{array}$} \\
\hline Jan 20- Jan 22 & $\begin{array}{l}\text { Attended a conference at Singapore with delegates } \\
\text { from China }\end{array}$ & & \\
\hline Jan 23 & $\begin{array}{l}\text { Had fever, cough and runny nose } \\
\text { Took a flight from Singapore to KLIA, Malaysia } \\
\text { Met wife at the airport } \\
\text { Flight to Penang Airport, Penang state } \\
\text { Fetched by the sister, Mdm B } \\
\text { Treatment from a private clinic at Kuala Muda } \\
\text { District, Kedah state } \\
\text { Had dinner at a restaurant next to a private clinic } \\
\text { Stayed at mother's house at Kuala Muda district }\end{array}$ & $\begin{array}{l}\text { Went with daughter to fetch brother (Mr. A) and his } \\
\text { wife from Penang Airport } \\
\text { Directly brought Mr. A to a private clinic with others } \\
\text { on the same trip } \\
\text { Dinner with Mr. A and others }\end{array}$ & \\
\hline Jan 24 & $\begin{array}{l}\text { Stayed at mother's house throughout the day } \\
\text { Had meals at home with mother and wife, and } \\
\text { additionally with Mdm B and family for dinner }\end{array}$ & $\begin{array}{l}\text { Went to the grocery store and wet market } \\
\text { Went with husband, son, and daughter to mother's } \\
\text { house and had dinner with Mr. A and his wife }\end{array}$ & \\
\hline Jan 25 & $\begin{array}{l}\text { Stayed at mother's house, no other people except } \\
\text { mother and wife } \\
\text { Sought treatment at a private hospital }\end{array}$ & $\begin{array}{l}\text { Went to mother's house Visited relatives at Penang } \\
\text { state } \\
\text { Brought Mr. A to a private hospital for treatment }\end{array}$ & \\
\hline Jan 26 & $\begin{array}{l}\text { Lunch at mother's house } \\
\text { Talked with another sister from Penang state } \\
\text { Took a flight from Penang Airport to KLIA } \\
\text { Had dinner with relatives at Petaling district, } \\
\text { Selangor state ( } 36 \text { attendees, including mother-in- } \\
\text { law, Mdm C) }\end{array}$ & $\begin{array}{l}\text { Went to mother's house } \\
\text { Met sister from Penang state at mother's house } \\
\text { Sent Mr. A and his wife to Penang airport, together } \\
\text { with husband and daughter } \\
\text { Went to the cinema at Kuala Muda district with } \\
\text { family }\end{array}$ & $\begin{array}{l}\text { Had dinner with relatives including Mr. A } \\
\text { (36 attendees) }\end{array}$ \\
\hline Jan 27 & $\begin{array}{l}\text { Lunch with the same relatives including Mdm C at } \\
\text { Petaling District, Selangor } \\
\text { Dinner with the same relatives including Mdm C at } \\
\text { Petaling district, Selangor state }\end{array}$ & $\begin{array}{l}\text { Went to mother's house for dinner } \\
\text { Went to the cinema at Kuala Muda district with } \\
\text { family }\end{array}$ & $\begin{array}{l}\text { Lunch with the same relatives including } \\
\text { Mr. A at Petaling district, Selangor state } \\
\text { Dinner with the same relatives including } \\
\text { Mr. A at Petaling district, Selangor state }\end{array}$ \\
\hline Jan 28 & $\begin{array}{l}\text { Lunch and dinner with family members including } \\
\text { Mdm C at Petaling District, Selangor state } \\
\text { Sought treatment at a private clinic at Petaling } \\
\text { District, Selangor State }\end{array}$ & $\begin{array}{l}\text { Bought breakfast at a local food court } \\
\text { Sent children to school and went to mother's house }\end{array}$ & \multirow[t]{6}{*}{$\begin{array}{l}\text { Stayed at home at Petaling district, } \\
\text { Selangor state, with husband, son, and } \\
\text { helper }\end{array}$} \\
\hline Jan 29- Jan 30 & \multirow[t]{3}{*}{$\begin{array}{l}\text { Went to a private hospital at Selangor state, admitted } \\
\text { and treated }\end{array}$} & $\begin{array}{l}\text { Sent children to school and went to mother's house } \\
\text { and }\end{array}$ & \\
\hline Jan 31 & & $\begin{array}{l}\text { Went to sister's house at Penang state with mother } \\
\text { and daughter } \\
\text { Had a meal with family members at a food court in } \\
\text { Penang state }\end{array}$ & \\
\hline Feb 1 & & $\begin{array}{l}\text { Had a fever and sore throat Bought medication at a } \\
\text { private clinic at Kuala Muda District, Kedah state }\end{array}$ & \\
\hline Feb 2 & $\begin{array}{l}\text { Referred as PUI to the public hospital in Selangor } \\
\text { state }\end{array}$ & Went to mother's house and stayed at home & \\
\hline Feb 3 & $\begin{array}{l}\text { Laboratory-confirmed as positive for COVID-19 } \\
\text { Contact tracing: } 60 \text { contacts }\end{array}$ & $\begin{array}{l}\text { Went to the workplace at Baling district, Kedah state } \\
\text { and met } 5 \text { co-workers } \\
\text { Went to mother's house }\end{array}$ & \\
\hline Feb 4 & \multirow[t]{5}{*}{ Treated at the public hospital at Selangor state } & $\begin{array}{l}\text { Sent children to school and went to mother's house } \\
\text { Interviewed by RAT from Kuala Muda DHO, Kedah } \\
\text { state } \\
\text { Home quarantine } \\
\text { Swab taken, together with family, at a public } \\
\text { hospital in Kuala Muda District, Kedah state. }\end{array}$ & $\begin{array}{l}\text { Stayed at home at Petaling district, } \\
\text { Selangor state, with husband, son, and } \\
\text { helper }\end{array}$ \\
\hline Feb 5 & & $\begin{array}{l}\text { Laboratory-confirmed as positive for COVID-19 } \\
\text { Contact tracing: } 12 \text { contacts } \\
\text { Admitted by RRT to a public hospital at Kedah state }\end{array}$ & $\begin{array}{l}\text { Brought to a private hospital for dizziness, } \\
\text { sweatiness and lethargy, no fever } \\
\text { Had a CT-brain and sent home }\end{array}$ \\
\hline Feb 6 & & \multirow[t]{6}{*}{ Treated at Public Hospital at Kedah state } & $\begin{array}{l}\text { Stayed at home at Petaling district, } \\
\text { Selangor state, with husband, son, and } \\
\text { helper }\end{array}$ \\
\hline Feb 7 & & & $\begin{array}{l}\text { Had MRI brain at the same private } \\
\text { hospital } \\
\text { Brought to the public clinic for swab } \\
\text { as the contact for Mr. A and home } \\
\text { quarantined }\end{array}$ \\
\hline Feb 8 & & & $\begin{array}{l}\text { Laboratory-confirmed as positive for } \\
\text { COVID-19 } \\
\text { Contact tracing: } 36 \text { contacts }\end{array}$ \\
\hline Feb 9-Feb 16 & & & \multirow{2}{*}{$\begin{array}{l}\text { Admitted by RRT to a public hospital at } \\
\text { Selangor state }\end{array}$} \\
\hline $\begin{array}{l}\text { Feb } 17 \\
\text { Feb } 18\end{array}$ & \multirow[t]{3}{*}{ Discharged with home quarantine for 14 days } & & \\
\hline Feb 19 & & & Discharged with home quarantine for \\
\hline Feb 22 & & Discharged with home quarantine for 14 days & 14 days \\
\hline
\end{tabular}


stage of COVID-19 in Malaysia, several limitations were found. Some potential contacts were not traced, such as contacts among passengers of Penang-KLIA flight when Mr. A travels back from Penang on 26 January. Only two passengers from Singapore-KLIA flight and three passengers from KLIA-Penang flight were traced. For Mdm B, contacts of two occasions when she went to a cinema for movies were not able to be traced, as the cinema management do not keep details of their audience. The large number of contacts traced for Mr. A also caused bottle neck in sampling, resulting in Mdm C being sampled and given home quarantine only three days after she was traced, leading to the relatively large number of contacts for a person with restricted mobility.

Public health intervention depends on updated knowledge of COVID-19 infection. Subsequent to the detection of the first local transmission cluster in Malaysia, as more was revealed about this new virus and more countries were affected by the pandemic, the National CPRC updated its guidelines from time to time to ensure more PUIs and cases were detected. ${ }^{27-29}$ In addition, realising the importance of risk communication in the management of COVID-19 in Malaysia, the Director General of Health of Malaysia and Minister of Health began to hold press conferences daily to update about the current situation of COVID-19 outbreak in Malaysia to the public. The $\mathrm{MOH}$ also began to become more aggressive in educating the public on COVID-19 through interviews and talk shows in various media, as well as through official websites, Facebook, Twitter, and Telegram. Travel advisories were also issued, which covered Wuhan City of Hubei Province as a whole initially, and quickly covered more and more countries. Currently, following the reduction in the COVID-19 infection due to various containment strategies, Malaysia is planning to open up its borders to international travellers with strict Standard Operating Procedures to prevent new infection clusters.

\section{Conclusion}

The preparedness and public health response adopted by the Malaysia CPRC were successful in detecting and controling the first local transmission cluster of COVID-19 in Malaysia. It also led to the detection of the hotel-link cluster in Singapore, from where the index case in this cluster was initially exposed to. This success was mainly attributed to swift case investigation, effective contact tracing, accurate diagnostics, and proper isolation of cases and quarantine of close contacts. Gaps in surveillance encountered in the process were improved upon subsequently. Malaysia CPRC experience can serve as a learning opportunity for other countries in the management of COVID-19, as well as other outbreaks in the future.

\section{Authors' Contributions}

NAA and CZL contributed to the study concept, literature search, data analysis, and writing of the report. SAR, MHG, MSAZ, and WNWMN, contributed to the literature search, data analysis, and writing of the report. EEN, SR, ZZ, and SMT contributed to the epidemiological data collection and analysis. All authors read and approved the final manuscript.

\section{Conflict of Interest Disclosures}

The authors declare that they have no known competing financial interests or personal relationships that could have appeared to influence the work reported in this paper.

\section{Ethical Approval}

This article was based on the findings from the investigation conducted under the Prevention and Control of Infectious Disease Act 1988 (Act 342). This publication is part of the study registered and approved by the Ministry of Health's Medical and Research Ethics Committee (NMRR-20-72054598)

\section{Funding/Support}

None.

\section{Acknowledgments}

The authors thank the Director General of Health for his permission to publish this article. We would like to express our gratitude to all healthcare providers in Malaysia who risk their lives in the management of COVID-19 in Malaysia.

\section{References}

1. World Health Organization (WHO). Novel Coronavirus (2019nCoV): Situation Report - 1. WHO; 2020. https://www.who.int/ docs/default-source/coronaviruse/situation-reports/20200121 sitrep-1-2019-ncov.pdf?sfvrsn=20a99c10_4. Accessed March 20, 2020.

2. World Health Organization (WHO). Naming the Coronavirus Disease (COVID-19) and the Virus that Causes it. WHO; 2020. https://www.who.int/emergencies/diseases/novel-coronavirus-2019/technical-guidance/naming-the-coronavirus-disease(covid-2019)-and-the-virus-that-causes-it. Accessed March 20, 2020.

3. 3. World Health Organization (WHO). Coronavirus Disease (COVID-19): Situation Report - 159. WHO; 2020. https:// www.who.int/docs/default-source/coronaviruse/situationreports/20200627-covid-19-sitrep-159.pdf?sfvrsn=93e027f6_2. Accessed June 28, 2020.

4. Ministry of Health of Malaysia. DG Press Statement 28 June 2020 - Current Situation of Coronavirus Disease 2019 (COVID-19) in Malaysia 2020. https://kpkesihatan.com/2020/06/28/kenyataanakhbar-kpk-28-jun-2020-situasi-semasa-jangkitan-penyakitcoronavirus-2019-covid-19-di-malaysia/. Accessed June 28, 2020.

5. Ministry of Health of Malaysia. Press Statement of Director General of Health Malaysia - 25 January 2020. 2020. http://www.moh. gov.my/index.php/database_stores/store_view_page/21/1301. Accessed April 1, 2020.

6. Ministry of Health of Malaysia. Press Statement of Director General of Health Malaysia - 30 January 2020. 2020. http://www.moh. gov.my/index.php/database_stores/store_view_page/21/1306. Accessed April 1, 2020.

7. First Locally Transmitted Case of Novel Coronavirus in Malaysia, Total Cases Rise to 14. CNA. 2020. https://www.channelnewsasia. com/news/asia/wuhan-coronavirus-malaysia-locallytransmitted-12401166. Accessed April 1, 2020.

8. Ministry of Health of Malaysia. Press Statement of Director General of Health Malaysia - 6 January 2020. 2020. http://www.moh. gov.my/index.php/database_stores/store_view_page/21/1288. Accessed April 9, 2020.

9. Ministry of Health of Malaysia. Press Statement of Director General 
of Health Malaysia - 23 January 2020. 2020. http://www.moh. gov.my/index.php/database_stores/store_view_page/21/1299. Accessed April 9, 2020.

10. Wan Mohamed Noor WN, Sandhu SS, Ahmad Mahir HM, et al. Responding to the potential of Ebola virus disease (EVD) importation into Malaysia. Malays J Med Sci. 2014;21(6):3-8.

11. Premila Devi J, Noraini W, Norhayati R, et al. Laboratoryconfirmed case of Middle East respiratory syndrome coronavirus (MERS-CoV) infection in Malaysia: preparedness and response, April 2014. Euro Surveill. 2014;19(18). doi:10.2807/1560-7917. es2014.19.18.20797.

12. Ministry of Health of Malaysia. Interim Guidelines Novel Coronavirus (nCoV) Management in Malaysis 2020. Ministry of Health of Malaysia; 2020.

13. Government of Malaysia. Prevention and Control of Infectious Disease Act 1988. Government of Malaysia; 1988.

14. Ministry of Health of Malaysia. Malaysis Influenza Surveillance Protocol. In: Surveillance Sector DCD, editor.: Ministry of Health Malaysia; 2015 http://www.moh.gov.my/moh/resources/Garis\%20 Panduan\%20Penyakit/MALAYSIA_INFLUENZA_SURVEILLANCE_ PROTOCOL.pdf. Accessed April 1, 2020.

15. Ministry of Health of Malaysia. Press Statement of Director General of Health Malaysia - 26 January 2020. http://www.moh.gov.my/ index.php/database_stores/store_view_page/21/1302. Accessed April 1, 2020.

16. Hassan H. Malaysia Confirms First Citizen with Coronavirus: Man was in S'pore for Meeting with China Colleagues Last Month. The Straits Times. 2020. https://www.straitstimes.com/asia/se-asia/ coronavirus-malaysia-confirms-first-citizen-infected-with-virustotal-cases-now-10. Accessed April 1, 2020.

17. Malaysian COVID-19 Patient Linked to Grand Hyatt Singapore Meeting Discharged. CNA. February 17, 2020. https://www. channelnewsasia.com/news/asia/malaysia-covid-19-coronavirusgrand-hyatt-servomex-recovered-12442252. Accessed April 1, 2020.

18. Pung R, Chiew CJ, Young BE, et al. Investigation of three clusters of COVID-19 in Singapore: implications for surveillance and response measures. Lancet. 2020;395(10229):1039-1046. doi:10.1016/s0140-6736(20)30528-6.

19. Bernard Stoecklin S, Rolland $P$, Silue $Y$, et al. First cases of coronavirus disease 2019 (COVID-19) in France: surveillance, investigations and control measures, January 2020. Euro Surveill. 2020;25(6). doi:10.2807/1560-7917.es.2020.25.6.2000094.
20. Wu Z, McGoogan JM. Characteristics of and important lessons from the coronavirus disease 2019 (COVID-19) outbreak in China: summary of a report of 72314 cases from the Chinese Center for Disease Control and Prevention. JAMA. 2020. doi:10.1001/ jama.2020.2648.

21. Coronavirus disease-19: summary of 2,370 contact investigations of the first 30 cases in the republic of Korea. Osong Public Health Res Perspect.2020;11(2):81-84.doi:10.24171/j.phrp.2020.11.2.04.

22. Early epidemiological and clinical characteristics of 28 cases of coronavirus disease in South Korea. Osong Public Health Res Perspect. 2020;11(1):8-14. doi:10.24171/j.phrp.2020.11.1.03.

23. World Health Organization (WHO). Report of the WHO-China Joint Mission on Coronavirus Disease 2019 (COVID-19). WHO; 2020.

24. Chen S, Yang J, Yang W, Wang C, Bärnighausen T. COVID-19 control in China during mass population movements at New Year. Lancet. 2020;395(10226):764-766. doi:10.1016/s01406736(20)30421-9.

25. Li P, Fu JB, Li KF, et al. Transmission of COVID-19 in the terminal stages of the incubation period: a familial cluster. Int J Infect Dis. 2020;96:452-453. doi:10.1016/j.ijid.2020.03.027.

26. Qian G, Yang N, Ma AHY, et al. A COVID-19 Transmission within a family cluster by presymptomatic infectors in China. Clin Infect Dis. 2020. doi:10.1093/cid/ciaa316.

27. Ministry of Health of Malaysia. Guideline 2019-nCoV Management No,3/2020 Update on 8 February 2020. Ministry of Health Malaysia; 2020. http://www.moh.gov.my/moh/resources/ Penerbitan/Garis\%20Panduan/Pengurusan\%20KEsihatan\%20 \&\%20kawalan\%20pykit/2019nCOV/13\%20FEB/Annex\%20 9\%20Management $\% 20$ of $\% 202019 \% 20$ nCoV\%20PoE_v3.pdf. Accessed April 25, 2020.

28. Ministry of Health of Malaysia. Guideline COVID-19 Management No.4/2020 Update on 26 February 2020. Ministry of Health Malaysia; 2020. http://www.moh.gov.my/moh/resources/ Penerbitan/Garis\%20Panduan/Pengurusan\%20KEsihatan\%20 \&\%20kawalan\%20pykit/2019-nCOV/Bil\%204\%20\%202020/ Pages_26022020.pdf. Accessed April 25, 2020.

29. Ministry of Health of Malaysia. Guidelines COVID-19 Management No.5/2020 Updated on 24 March 2020. Ministry of Health Malaysia; 2020. http://www.moh.gov.my/moh/resources/ Penerbitan/Garis\%20Panduan/COVID19/Annex_32_Quarantine_ centre_22032020.pdf. Accessed April 25, 2020 